Annie-Maj Johansson har disputerat i didaktik med inriktning mot naturvetenskap vid Stockholm universitet, Institutionen för matematikämnets och naturvetenskapsämnenas didaktik. Arbetar idag som lektor vid Högskolan Dalarna.

Per-Olof Wickman är professor i didaktik med inriktning mot naturvetenskap, Stockholms universitet, Institutionen för matematikämnets och naturvetenskapsämnenas didaktik, Stockholms universitet.

ANNIE-MAJ JOHANSSON

Högskolan Dalarna, Sverige

ajn@du.se

\title{
Selektiva traditioner i grundskolans tidigare år: Lärares betoningar av kvalitéer i naturveten- skapsundervisningen
}

\begin{abstract}
The aim of this study was to elucidate the selective traditions of Swedish primary school teachers in using inquiry-based learning. Material from thirteen interviews where teachers described their own inquiry practice was used to study the selective traditions along with the qualities these traditions emphasized. Four different selective traditions were identified: the fact oriented, the activity oriented, the collaboration oriented and the community oriented traditions. Different qualities were emphasized in the different traditions, for instance regarding whether teaching and inquiry should be difficult, correct, free or fun.
\end{abstract}

\section{INLEDNING}

I denna artikel studerar vi hur lärare beskriver och värderar hur de undervisar ett för dem relativt nytt arbetssätt, det undersökande arbetssättet med skolutvecklingsprogrammet NTA, och hur arbetssättet integreras i tidigare undervisningstraditioner. När ett nytt arbetssätt implementeras i tidigare traditioner kan dessa redan existerande traditioner fungera som tolkningsramar för vad som inkluderas eller exkluderas i den "nya" (Englund, 1986; Fensham, 1988; Sund \& Wickman, 2008; Williams, 1973; Öhman, 2004; Östman, 1995). Williams (1973) kallar denna process, genom vilken en kulturs traditioner tar sig vidare, för selektiva traditioner. Processen är alltid selektiv på ett sådant sätt att vissa meningar och praktiker betonas medan andra meningar och praktiker exkluderas (Williams, 1973). Vi har därför valt att i denna studie använda termen "selektiva traditioner" för det lärarna betonar ska inkluderas eller exkluderas i deras undervisning.

Utifrån Deweys (1922/2005) mening kan traditioner beskrivas som kollektiva vanor eller sedvänjor vilka till exempel finns inom skolkulturen. Lärare har för vana att välja och översätta visst innehåll till lärandeaktiviteter och att forma undervisning så att eleverna trivs, vilket är en del av lärarprofessionen. Dessa didaktiska val kan inom en skolkultur betraktas som självklara och bra. Därmed kan de vara svåra att upptäcka, förändra eller ifrågasätta. För att kunna reflektera över didaktiska val 
som kan betraktas som mer eller mindre vanemässiga, behöver vi göra dem synliga (Sandell, Öhman \& Östman, 2005). Det finns idag få studier som synliggör de värderingar och val som lärare för grundskolans tidigare årskurser beskriver i samband med undervisning med undersökande arbetssätt (e. g., Harlen, 1997).

Naturvetenskap och teknik för alla (NTA) är en satsning som gjorts för att utveckla den naturorienterade undervisningen i grundskolan. I dag deltar över en tredjedel av Sveriges kommuner i skolutvecklingsprojektet naturvetenskap och teknik för alla (NTA, www.nta.kva.se). NTA initierades av Kungliga Vetenskapsakademin och Kungliga Ingenjörsvetenskapsakademin tillsammans med några kommuner 1997. Genom att skolor medverkar i NTA får lärare förutom lärarhandledning också tillgång till konkret material och en kort utbildning i arbetssättet och valt tema. I och med att allt fler skolor använder NTA i undervisningen har det också blivit vanligare att lärare och elever i grundskolans tidigare år arbetar med undersökande arbetssätt. Det är därmed intressant att studera vad lärare för de yngre årskurserna väljer att inkludera eller utesluta vid undersökande arbetssätt i undervisning med NTA.

Idag pågår en internationell diskussion om vad elever ska lära sig genom att arbeta med undersökande arbetssätt. Inom denna debatt beskrivs främst tre olika syften för naturvetenskapliga undersökningar "scientific inquiry", nämligen att eleverna lär sig naturvetenskapliga förklaringar, att eleverna lär sig göra naturvetenskapliga undersökningar samt att eleverna utvecklar förståelse om naturvetenskapliga undersökningar (DeBoer, 1991). Att elever lär sig genomföra undersökningar innebär exempelvis, att de ska lära sig att formulera hypoteser eller att tolka data. Att eleverna utvecklar en förståelse om naturvetenskapliga undersökningar innebär till exempel, att elever utvecklar en förståelse om att naturvetenskapliga undersökningar vägleds av forskningsfrågor eller att naturvetenskapliga förklaringar utvecklas i ett samspel mellan data och tidigare kunskaper (Lederman \& Lederman, 2011).

I studien undersöker vi hur ett relativt nytt arbetssätt, undersökande arbetssätt genom NTA, integreras i lärares traditioner av att undervisa yngre elever. Genom att explicit beskriva dessa selektiva traditioner i naturvetenskap för yngre åldrar finns möjlighet att diskutera och utmana de traditioner och kvalitéer som annars kan tas förgivna.

\section{TEORETISKT RAMVERK}

För att undersöka hur lärare beskriver och värderar sitt arbete med ett undersökande arbetssätt med yngre elever i naturvetenskap, har vi valt att studera vilka estetiska, normativa och kognitiva kvalitéer lärare betonar och hur deras olika betoningar kan kategoriseras i skilda selektiva traditioner. I följande ramverk beskrivs hur selektiva traditioner och hur estetiska, normativa och kognitiva uttryck studerats tidigare. Därefter presenteras också kort olika möjliga syften för undersökande arbetssätt, eftersom dessa har betydelse för vilka kvalitéer som inkluderas eller exkluderas i undervisningen.

\section{Selektiva traditioner i undervisningen}

I studien har vi använt selektiva traditioner som ett centralt begrepp. Begreppet avser regelbundna val av innehåll vilka utvecklas inom en verksamhet under en längre tid. Dessa val av vad som inkluderas eller exkluderas i undervisningen bildar mönster av en specifik utbildningskultur. Flera tidigare studier har visat hur olika utbildningstraditioner har specifika förhållningssätt gentemot kunskap och utbildningspraktik (Englund, 1986; Fensham, 1988; Williams, 1973; Öhman, 2004; Östman, 1995). Dessa selektiva traditioner representerar olika syn på vad som är bra undervisning, på val av innehåll och på undervisningsmetoder. Val av vad som inkluderas eller exkluderas inom en verksamhet påverkas av till exempel sedvänjor, tidigare erfarenheter och andras åsikter inom verksamheten och de utgår från värderingar om vad som är viktigt, relevant, korrekt och så vidare (Almqvist, Kronlid, Quennerstedt, Öhman, Öhman \& Östman, 2008). Lärare kan fungera som traditionsbärare av vad som anses vara bra undervisning (Sund \& Wickman, 2008). Det kan därför vara intressant att se 
vilka traditioner som synliggörs när lärare värderar vad som är bra respektive dålig undervisning. Eftersom selektiva traditioner skapas och upprätthålls av det som sägs och görs i en verksamhet, har vi valt att använda termen "selektiva traditioner" för det lärarna betonar ska inkluderas eller exkluderas i deras undervisning, även om dessa val inte har studerats över längre tid.

Tidigare studier om selektiva traditioner bygger främst på analyser av texter som läroböcker, metodböcker och kursplaner. De berör också främst selektiva traditioner inom miljöundervisningen (Sandell, Öhman \& Östman, 2005; Sund \& Wickman, 2008; Öhman, 2004). Gyllenpalm, Wickman och Holmgren (2010) har genom intervjuer med tolv lärare för grundskolans senare årskurser studerat selektiva traditioner och undersökande arbete. I likhet med tidigare studier (jfr Högström, Ottander \& Benckert, 2005) fann de att lärarna inte beskrev undersökande arbete utifrån syftet att eleverna skulle lära sig göra naturvetenskapliga undersökningar eller utveckla förståelse om naturvetenskapliga undersökningar. Det finns idag många studier av undervisning med undersökande arbetssätt också i de tidigare årskurserna, framförallt i USA. Dessa omfattar dock i regel någon eller några lärares prioriteringar (e.g. Carlone, Haun-Frank \& Webb, 2011) och inte, som i detta fall, ett större antal lärares val och värderingar av innehåll och metoder.

\section{Estetiska, normativa och kognitiva uttryck}

I undervisning möter elever också de föreställningar, värderingar och normer som råder inom en verksamhet. Tidigare studier visar också hur användandet av estetiska, normativa och kognitiva uttryck har betydelse när vi talar med varandra (Jakobson \& Wickman, 2008; Wickman, 2006). Dessa uttryck används också av lärarna i intervjuerna för att värdera undervisningens olika kvalitéer

De olika typer av undervisningskvalitéer som vi här har valt att beskriva har sin grund i den traditionella indelningen av människans förmögenheter i förnuft (kognition), praktiskt förnuft (normer för handling) och omdöme (estetik inklusive känslor) (Wickman, 2006). Detta val är analytiskt för att inte förbise någon typ av värden i relation till hur lärarna värderar undervisningen i relation till eleverna. Samtidigt omfattar denna indelning också värderingar som är väsentliga för de tidigare beskrivna undervisningstraditionerna. Dessa estetiska, normativa och kognitiva uttryck är ofta sammanlänkade på ett sådant sätt att gränsen blir flytande i användningen (Jakobson \& Wickman, 2008; Wickman, 2006).

I intervjuerna använder lärarna estetiska uttryck för att beskriva undervisningen i termer av känslor, som gillande eller ogillande, eller för att uttrycka sin eller elevernas smak, till exempel om vad som är vackert eller fult (Wickman, 2006). Lärare använder estetiska omdömen om vad som är rätt att säga och göra i klassrummet. Därmed har lärares estetiska omdömen betydelse för elevernas möjligheter att trivas och att fortskrida i arbetet och på så sätt också för vad de har möjlighet att lära sig inom ämnesområdet (Jakobson, 2008; Wickman, 2006).

Normativa uttryck bidrar till att ange normen i klassrummet, till exempel i termer av vad som är rätt/ fel eller fritt/styrt. Normerna kan innebära att eleverna ska ta ansvar genom att ställa upp på skolans vardag med sina ordnings- och uppföranderegler och att de ska finna sig i den sociala ordningen (Permer \& Permer, 2002). Andra normer tillhör det naturvetenskapliga klassrummet, till exempel vad som tillhör eller inte tillhör naturvetenskap. Lärare använder både normativa och estetiska utryck för att ange de normer som gäller (Wickman, 2006).

Lärarnas kognitiva uttryck beskriver undervisningen i termer av hur den befrämjar elevers förståelse och kunskaper. Hit hör uttryck som beskriver undervisningen som lätt/svår eller som tydlig/otydlig för eleverna. 


\section{Undersökande arbetssätt}

Naturvetenskapliga undersökningar har varit ett mål i de svenska läroplanerna sedan 1960-talet. Från 1960-talet fram till 2000-talet har det skett flera förskjutningar angående syftet med undersökande arbetssätt, från en induktiv metod till en mer deduktiv metod och från en betoning på att eleverna genomför undersökningar till en betoning på en förståelse av naturvetenskapliga undersökningar. Vidare finns en förskjutning mot att behandla rapportering som en allt mer social och kommunikativ process, där eleverna även diskuterar och argumenterar (Johansson \& Wickman, 2012). Dessa olika syften kan därmed ses som betydelsefulla riktningsgivare för lärares arbete med undersökande arbetssätt. Högström, Ottander och Benckert (2006), som studerat lärares mål med laborativt arbete, visade att lärare dels uttryckte generella mål som kunskapsutveckling och förståelse, dels specifika mål för laborationer. De senare handlade framförallt om att skapa intresse och främja laborativa färdigheter snarare än förståelse av begrepp.

Tidigare studier av undervisning i grundskolans tidigare årskurser visar att lärare främst fokuserar på elevers görande (jfr Emanuelsson, 2001). Flera studier visar också att det är problematiskt för lärare att hjälpa elever med att relatera "görande" till mer naturvetenskapliga sammanhang (Duschl, 2008). Det är därmed intressant att studera vilka värderingar som framkommer i lärares beskrivning av sin egen undervisning med undersökande arbetssätt i grundskolans tidigare årskurser och på så sätt synligöra lärarens och elevens roll samt undervisningens syfte.

\section{SYFTE OCH FRÅGESTÄLLNING}

I denna studie belyser vi selektiva traditioner i naturvetenskap för grundskolans tidigare åldrar, årskurs F-6, utifrån lärares beskrivningar i intervjuer av sin egen undervisning med undersökande arbetssätt. För att ta reda på hur dessa lärare beskriver och värderar det undersökande arbetssättet samt vilka selektiva traditioner som detta arbetssätt integreras i, har intervjuerna analyserats utifrån nedanstående frågor:

1. Vilka selektiva traditioner finns i lärarnas beskrivning av sin egen undervisning?

2. Vilka olika kvalitéer i undervisning med undersökande arbetssätt betonar de här traditionerna?

3. Vad betyder betoningen i traditionerna för det innehåll som eleverna erbjuds?

\section{METOD}

\section{Studiens sammanhang}

Vid insamlingen av data gällde läroplanen Lpo 94 (Skolverket, 1994) och Kursplan 2000 (Skolverket, 2000) för de naturvetenskapliga ämnena (kallas naturorienterande ämnen, NO). Läroplanen var målstyrd och beskrev alltså de mål eleverna skulle uppnå eller de mål undervisningen skulle sträva mot. Läroplanen lämnade därmed över till lärare att besluta om hur undervisningen skulle genomföras. Lärarna i studien undervisade i naturvetenskap med hjälp av skolutvecklingsprojektet NTA. NTA utgår från en amerikansk motsvarighet (Science and Technology for Children) baserad på inquiry based learning, eller på svenska ett undersökande experimenterande arbetssätt. Målet är att stimulera och hjälpa grundskolans lärare och elever med undervisningen i naturvetenskap och teknik utifrån olika färdiga teman med detaljerade lärarhandledningar och ibland även med elevhandledningar. Varje tema består av sammanlagt cirka tolv till femton uppdrag. Läraren spelar en stor roll i undervisningen för att hjälpa eleverna att närma sig ett mer naturvetenskapligt sätt att förstå.

Intervjuerna genomfördes med tjugo lärare vid tretton tillfällen. Några av intervjuerna var gruppintervjuer medan andra genomfördes med enskilda lärare. De lärare som deltog vid gruppintervjuerna hade samarbetat aktivt med ett gemensamt tema och berättade därför tillsammans om deras arbete utifrån valt tema. En konsekvens av detta var att dessa lärare oftast var eniga om hur de arbetat och varför de valt detta arbetssätt. Därmed har dessa lärares beskrivningar också kommit att likna varandra. Lärarna, fjorton kvinnor och sex män, arbetade alla i grundskolans tidigare årskurser, från 
förskoleklass till årskurs sex. Den svenska grundskolan består av nio obligatoriska årskurser (1-9). Innan årskurs ett finns ett frivilligt skolår, förskoleklass (F), men som också är reglerat av läroplanen. Av de intervjuade lärarna hade alla arbetat med flera olika NTA-teman. Nio lärare hade undervisat i NO tidigare utan hjälp av NTA, medan elva lärare uppgav att de börjat undervisa i NO först med hjälp av NTA.

Intervjuerna var semistrukturerade (Kvale, 1997). Vid intervjuerna ombads lärarna att berätta om sin egen undervisning utifrån ett NTA-tema de själva valt. Frågor ställdes som stöd för att lärarna skulle komma vidare i sina berättelser om sitt tema eller för att förtydliga vad lärarna beskrev. Exempel på frågor var: "Berätta hur du börjar uppdraget?” och "Kan du ge exempel på en sådan situation?" Lärarna var välvilligt inställda till att berätta om arbetet och flera hade förberett intervjuerna genom att ta med material eller anteckningar. Även om alla lärare inte kom ihåg precis hur de arbetat med alla uppdrag inom valt tema, så berättade alla lärare om flertalet uppdrag på ett trovärdigt sätt, ofta med hjälp av olika exempel. Vid flera tillfällen jämfördes eller beskrevs flera teman som läraren arbetat med. Varje intervjutillfälle började med att vi tillsammans samtalade lite kort om det valda temat, hur många gånger lärarna haft temat, när de gick utbildningen för aktuellt tema, vad som var speciellt för just det temat och så vidare.

Intervjuerna varade i cirka 60 minuter, spelades in och har därefter transkriberats. Alla informanter i studien informerades om att deras deltagande var frivilligt och att de kunde avbryta deltagandet när de så önskade. Vidare garanterades att informanterna skulle få vara anonyma.

\section{Analys}

För att besvara forskningsfrågorna har vi först besvarat följande frågeställningar:

1. Vilka delar av lärarnas berättelser beskriver ett undervisningsinnehåll och har ett elevdeltagande?

2. Vilka av dessa ovanstående delar exkluderas eller inkluderas i undervisningen?

3. Vilka estetiska, normativa och kognitiva uttryck använder lärarna för att beskriva de kvalitéer som exkluderas eller inkluderas i undervisningen?

4. Vilka selektiva traditioner kan identifieras utifrån ovanstående kvalitéer?

Först fokuserades de delar av lärarnas berättelser som beskriver deras arbete med elevers lärande gentemot ett visst undervisningsinnehåll (steg 1). Dessa delar av lärarnas berättelser karaktäriserades därefter som kvalitéer och vi sorterade dem utifrån om lärarna exkluderar eller inkluderar dem som önskvärda i undervisningen (steg 2). Därefter analyserade vi vilka estetiska, normativa och kognitiva uttryck lärarna använder för att beskriva de kvalitéer som inkluderas eller exkluderas i undervisningen (steg 3). Slutligen identifierades fyra olika selektiva traditioner (steg 4). För att synliggöra de föreställningar, värderingar och normer som förekommer har vi valt att utgå från de estetiska, normativa och kognitiva uttryck som lärarna använder för att motivera sitt val angående innehåll och arbetsmetoder. De estetiska uttrycken användes för att till exempel beskriva barnens känslor, vad de tycker är roligt/tråkigt eller intressant/ointressant och normativa uttryck används för att beskriva normen för eleverna, till exempel vad som är rätt/fel eller fritt/styrt. Lärarna använder kognitiva uttryck för att bland annat beskriva undervisning som lätt/svår eller begriplig/obegriplig.

Analysmetoden bygger på Kvales (1997) beskrivning av meningskategorisering. I enlighet med denna metod har lärarnas uttalanden i intervjuerna reducerats till enskilda kategorier. För att förklara de olika stegen i analysen använder vi här följande exempel från intervjun med Ritva, som beskriver sin undervisning med NTA-temat Magneter och motorer: 
1. Ritva: Men jag kände att nu måste de liksom kunna få börja följa.

2. Intervjuare: $\mathrm{Mm}$.

3. Ritva: Utan attjag ska ha gått igenom så mycket innan, och det var jättesvårt, men de lyckades, allihop gjorde ju, men det tog lång tid att bygga den här kompassen.

4. Intervjuare: $\mathrm{Mm}$.

5. Ritva: Men det var lite medvetet, jag kände att, nej nu vill jag att de fär öva och följa instruktionen, svårt var det, otroligt svårt.

I det första steget valde vi ut de delar av intervjuerna som beskriver hur lärarna talar om ett visst innehåll i undervisningen och ett elevdeltagande. Ritva: Utan att jag ska ha gått igenom så mycket innan (...) men det tog lång tid att bygga den här kompassen. Ritva beskriver i turtagning 3 att eleverna skulle bygga kompassen utan att hon gått igenom så mycket innan. Det är eleverna som ska genomföra byggandet, så det finns ett tydligt elevdeltagande och de ska bygga en kompass utan att läraren gått igenom så mycket innan, vilket är ett tydligt ämnesinnehåll.

I det andra steget kategoriserade vi dessa undervisnings- och elevdeltagande delar utifrån om de inkluderas eller exkluderas i undervisningen. Ritva säger till exempel i turtagning 5: Men det var lite medvetet, jag kände att, nej nu vill jag att de får öva och följa instruktionen, svårt var det, otroligt svårt. Ritva beskriver att hon gjort detta medvetet och att hon ville att eleverna skulle få öva på att följa instruktioner. Eftersom det var medvetet, har vi kategoriserat denna del av undervisningen som inkluderad i undervisningen.

I det tredje steget markerades de kognitiva, estetiska och normativa uttryck som lärarna använde. Ritva använder uttrycken jättesvårt i turtagning 3 samt svårt och otroligt svårt i turtagning 5, vilka markerades som kognitiva uttryck. Därför kategoriserades svårt att följa instruktioner som en kognitiv kvalitet i undervisningen.

I det fjärde steget kategoriserade vi hur lärarna talade om olika delars kvalitéer i undervisningen. Genom sortering av de olika delar av undervisningen lärarna beskrev och värderade i termer av olika kvalitéer, till exempel att följa instruktioner, framkom vissa återkommande mönster i lärarnas berättelser, vilka kunde kategoriseras i selektiva traditioner. De kognitiva, estetiska eller normativa uttrycken, till exempel svårt eller lätt, kunde därmed placeras i flera olika traditioner. Kategoriseringen av kvalitéerna i lärarnas samlade berättelser i traditioner gjordes genom upprepade cykler av läsning och diskussioner där båda författarna deltog. Kategoriseringarna har också presenterats och diskuterats vid forskarseminarier vid vår institution. Detta fortgick tills samförstånd nåddes mellan författarna. Denna första systematisering resulterade i fyra undervisningstraditioner. Denna kategorisering gjordes alltså induktivt utifrån lärarnas berättelser i intervjuerna. Först därefter jämfördes dessa empiriskt funna undervisningstraditioner med de i litteraturen tidigare beskrivna undervisningstraditionerna.

\section{RESULTAT}

Studien tar sin utgångspunkt i hur lärare använder estetiska, normativa och kognitiva uttryck. Dessa uttryck används på flera sätt för att beskriva vad som inkluderas respektive exkluderas i undervisningen med NTA.

Genom upprepad läsning av kvalitéerna ser vi att det finns vissa kvalitéer som återkommer och är gemensamma för vissa lärare. På så sätt identifierades fyra olika selektiva traditioner. Dessa har vi valt att kalla för den 1) faktaorienterade, 2) aktivitetsorienterade, 3) samarbetsorienterade samt 4) kommunikationsorienterade traditionen. Tabell 1 ger exempel på vilka kvalitéer som ingår i de olika traditionerna. 
Tabell 1. Exempel på de kvalitéer som inkluderas (I) och exkluderas (E) inom de olika selektiva traditionerna

\begin{tabular}{|c|c|c|c|c|c|}
\hline & Kvalitéer & 吾 & 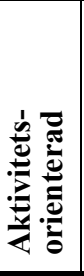 & 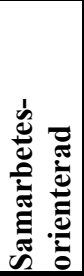 & 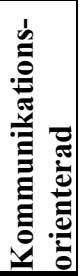 \\
\hline \multirow{7}{*}{ 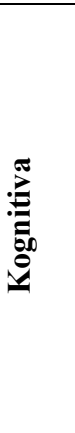 } & Svårt att följa instruktioner inkluderas & $\overline{\mathrm{I}}$ & & $\bar{I}$ & $\bar{I}$ \\
\hline & $\begin{array}{l}\text { Svårt att reflektera själva kring det undersökande arbetet, } \\
\text { inkluderas }\end{array}$ & I & & & \\
\hline & Svårt att lita på sin egen förutsägelse, inkluderas & I & & & \\
\hline & $\begin{array}{l}\text { Svårt att ta ansvar och samarbeta inom gruppen, } \\
\text { inkluderas }\end{array}$ & & & I & \\
\hline & Svårt att förstå naturvetenskapliga begrepp, inkluderas & & & & I \\
\hline & $\begin{array}{l}\text { Svårt att läsa texter, dokumentera, nya begrepp, } \\
\text { exkluderas }\end{array}$ & $\mathrm{E}$ & $\mathrm{E}$ & & \\
\hline & Svårt att få eleverna engagerade i pratmoment, exkluderas & & $\mathrm{E}$ & & \\
\hline \multirow{10}{*}{ 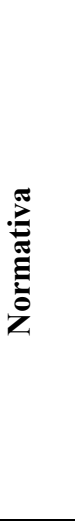 } & Följa instruktionerna riktigt, inkluderas & $\mathrm{I}$ & & & \\
\hline & $\begin{array}{l}\text { Förändra uppdragen så att de blir mer på riktigt, anknyter } \\
\text { till verkligheten, inkluderas }\end{array}$ & & & I & \\
\hline & $\begin{array}{l}\text { Arbetar fritt i form av lite mera öppna undersökningar, } \\
\text { inkluderas }\end{array}$ & & & & I \\
\hline & $\begin{array}{l}\text { Att utveckla en vana av att arbeta undersökande, } \\
\text { inkluderas }\end{array}$ & & & & I \\
\hline & Praktiskt arbete som problematiskt, inkluderas & I & & & \\
\hline & Praktiskt arbete som en avkoppling, inkluderas & & I & & \\
\hline & Praktiskt arbete som positiva upplevelser, inkluderas & & I & I & \\
\hline & Komma fram till rätt resultat, inkluderas & I & & & \\
\hline & Komma fram till rätt resultat, exkluderas ibland & & $\mathrm{E}$ & E & \\
\hline & Lärarstyrd undervisning, exkluderas & & & $\mathrm{E}$ & \\
\hline \multirow{3}{*}{ 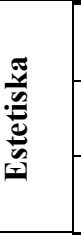 } & $\begin{array}{l}\text { Förändrar uppdragen så att eleverna får använda } \\
\text { nyfikenhet och kreativitet, inkluderas }\end{array}$ & & & I & \\
\hline & $\begin{array}{l}\text { Upplevelser av NO-undervisningen som intressant och } \\
\text { spännande, inkluderas }\end{array}$ & & I & I & I \\
\hline & $\begin{array}{l}\text { Upplevelser av NO-undervisning som tråkig eller jobbig, } \\
\text { exkluderas }\end{array}$ & & E & $\mathrm{E}$ & \\
\hline \multirow{2}{*}{ 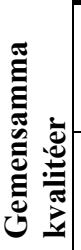 } & Förutsägelser får vara $f e l$, inkluderas & I & I & I & I \\
\hline & NO-undervisning innebär praktiskt arbete, inkluderas & I & I & I & I \\
\hline
\end{tabular}


De fyra selektiva traditionerna vi funnit tar därmed sin utgångspunkt i det eller de NTA-teman läraren valt att berätta om. Även om lärarna valt olika teman och dessa teman är uppbyggda på lite olika sätt så finns gemensamma drag och arbetssätt, vilket gör det möjligt att jämföra lärarnas beskrivningar. Lärarna har också arbetat med flera olika teman och under intervjuerna beskriver de flera teman genom att jämföra och dra paralleller mellan dem. Vi vill poängtera att de selektiva traditioner vi identifierar kan ses som betoningar av de medvetna eller omedvetna val lärarna gör i undervisningen och under intervjuerna. Traditionerna ska inte ses som något som lärarna är eller som absoluta beskrivningar av hur undervisningen bedrivs. Lärarnas betoningar av kvalitéerna inom traditionerna är inte heller helt entydiga utan överlappar varandra.

\section{Faktaorienterade traditionen}

Inom den faktaorienterade traditionen (återfanns hos 4 lärare i 3 intervjuer) används främst kognitiva och normativa uttryck, vilka exemplifieras med citat från intervjuerna. Lärarna talar här till exempel om hur svårt det är för eleverna att följa instruktioner, samtidigt som det betonas att eleverna behöver följa instruktionerna rätt för att på så sätt komma fram till ett förutbestämt rätt resultat (6-8).

6. Ida: Jaa, det var ju det här med, vad kallas det här med, de här icke drivande axlarna, det var en pojke, han tänkte skruva på ett helt annat sätt alltså.

7. Harry: $M m$.

8. da: Ja men du, dina resultat de är ju inte värda någonting, för du har inte haft utgångspunkten, de gäller ju inte, för du har ju byggt din bil på ett annat sätt, nu måste du sätta om, och bygga om det här.

Intervjuutdraget nedan visar ett exempel på ett normativt uttryck där "rätt och fel" används för att beskriva att elevernas förutsägelser eller gissningar får vara fel. Eleverna behöver lära sig att lita på vad de själva tycker (9-11). Även om resultatet visar att eleverna gissat fel, kan inte förutsägelserna eller gissningarna i sig vara fel, eftersom dessa talar om vad eleverna tror. Även i detta sammanhang uttrycks arbetsätt där det finns ett rätt eller sant resultat.

9. Fanny: Som kanske inte visar sig är sant, liksom det där med att gissa liksom. Jag säger det kan inte bli, det finns inga rätt eller fel utan du ska bara gissa och du ska känna efter och om kompisen säger två och du tycker en, då är det väl en för dig.

10. Intervjuare: $M m$.

11. Fanny: Just som att lita på sig själv. Det där märkte jag, nu hade vi det precis i dag och just det där, de hade väldigt svårt med det där.

Uttrycken "icke vana" och "praktiskt" beskrivs ha betydelse för om eleverna tar sig vidare i aktiviteten. Icke vana elever läser instruktionerna mera noggrant och kommer därmed fram till de rätta resultaten (12). Därmed beskrivs icke vana som något positivt.

12. Harry: Att man, att tjejer inte är vana att riktigt hålla på så här och då, då blir man, då är man, då ser man till att man, man läser instruktionerna så att man får det som det ska.

Det "praktiska" arbetet kan vara problematiskt om det lockar eleverna att göra annat än det planerade och beskrivs därmed inte enbart som positivt (13-15). På så sätt synliggörs också vissa normer vilka gäller i skolan och i det naturvetenskapliga klassrummet. Den naturvetenskapliga undervisningen beskrivs åtminstone delvis som praktisk och det praktiska arbetet har ett särskilt syfte eller mening.

13. Harry: Det måste ju, jag misstänker att det måste vara ett litet problem med rörelse och konstruktion, alltså så att hålla sig till, till ämnet, höll jag på att säga, att, för jag menar det är ju, det kan ju lika gärna bli bara något sorts lego. 
14. Ida: $M m$.

15. Harry: Lekstuga, där de, de gör saker och ting utan, utan mening.

Det kognitiva uttrycket "svårt" används för att beskriva vad som påverkar elevernas möjligheter att ta sig vidare i en aktivitet och hur detta påverkar lärarnas val av innehåll. Även om eleverna till exempel upplever att det är svårt att lita på sina förutsägelser eller att reflektera själva (16), så inkluderas dessa aktiviteter i undervisningen, medan andra aktiviteter, att läsa texter, dokumentera och möta nya begrepp, förändras eller utesluts (17).

16. Ida: Det är den där känslan man skulle vilja få fram, att man reflekterar själv i större utsträckning. Det är inte alltid så lätt tycker jag, barnen tycker att det är svårt.

17. Ida: Det var ganska kompakt text i rörelse och konstruktion, mycket att läsa för eleverna och det är svårt för barnen, det blir för avancerat alltså. Vi fick ju göra om för att det skulle var enklare.

\section{Aktivitetsorienterade traditionen}

Inom den aktivitetsorienterade traditionen (5 lärare i 3 intervjuer) läggs stor vikt vid elevernas positiva upplevelser. Lärarna uttrycker att "praktiskt arbete" fungerar som en avkoppling gentemot mer teoretiska arbeten (18). Det praktiska arbetet är en faktor vilken gör naturvetenskap eller undervisning mindre tråkig eller enformig.

18. Clara: De får ju arbeta med händer på ett helt annat sätt och tänk blir som en avkoppling, så att de, vi har ju inte så mycket praktiska saker $i$ skolan, så det blir som ett avbrott det här, både för elever och för lärare (...).

Även inom denna tradition förekommer termerna "rätt" eller "fel" även om det sker i mindre utsträckning än i den faktaorienterade traditionen. Det viktiga är inte att det blir rätt, utan att eleverna tycker att det är roligt eller intressant. Uttrycken "rätt" eller "fel" används främst vid beskrivning av att elevernas gissningar inte behöver vara rätt (19-21). Här betonas att eleverna behöver acceptera att deras gissningar kan vara fel. Därmed uttrycks att förutsägelserna i sig eller gissningarna kan vara fel, men att det inte har någon betydelse.

19. Jane: Men när man gissar så behöver det inte vara rätt svar, utan då forskar man, så det är bra tycker jag, bra på det sättet.

20. Intervjuare: Pratar ni om det också?

21. Jane: Ja och de är så otroligt rädda, en del de törs inte ens gissa men de får göra det, så att ja och blir det inte rätt så gör det ingenting.

Elevernas upplevelser av undervisningen beskrivs ha betydelse för om de kan ta sig vidare i sina aktiviteter eller inte. Hur eleverna upplever undervisningen făr därmed betydelse för lärares val av innehåll. Svåra aktiviteter eller aktiviteter där eleverna tröttnar, till exempel "pratmoment" och dokumentation utesluts i större utsträckning, medan roliga aktiviteter inkluderas i undervisningen (22-26). Lärarna talar samtidigt om det svåra kan vara positivt i undervisningen; eleverna behöver svåra utmaningar för att undervisningen inte ska upplevas som "värdelös" (27).

22. Jane: Det är också svårt $i$ tvåan nu, fast eller flytande för vissa, de tröttnar väldigt fort på tänkprat. Att tänka och analysera det är, tycker de inte riktigt bra om, det har de inte ro med barnen.

23. Intervjuare: Nej, nej.

24. Jane: Det är inte så många som har intresse av det kan jag säga, det är svårt att få dem engagerade $i$ det, jag tror att man måste liksom, det praktiska momenten det är de alltid engagerade i men pratmomenten, de är alltid svåra. 
25. Intervjuare: Hur gör du då, för att få dem engagerade?

26. Jane: Ja, man får minska ner på det, faktiskt.

27. Urban: Men att de ska ha så kul som möjligt och att det ska vara så förståeligt som möjligt men ändå innehålla moment och faktorer av utmaning, nästan för svårt om man säger så, att få den nivån att stämma är en otrolig utmaning, för att skulle de tycka att det här var lätt, så skulle de tycka att det var värdelöst.

Lärarna förändrar också undervisningen genom att lägga till eller ta bort moment för att eleverna ska uppleva undervisningen som rolig (28).

28. Urban: (...), så när man har fångat upp de här för tankarna och sedan gäller det och alltså första gången är ju väsentlig för vad de ska tycka om det, så de gäller ju att ha lite show, lite showtänk har jag.

\section{Samarbetsorienterade traditionen}

Den samarbetsorienterade traditionen (6 lärare i 3 intervjuer) har en stor betoning på elevernas förmåga att samarbeta i grupp. Gruppens förmåga att arbeta självständigt eller fritt betonas och är betydelsefull för att eleverna ska komma vidare i aktiviteten. Att gruppen arbetar självständigt eller fritt innebär att de följer givna instruktioner utan hjälp av läraren, något som beskrivs som svårt, men motiveras med att lärarstyrd undervisning är "tråkig" (29-31).

29. David: Och då, händer det utan att man behöver styra för mycket, då är det ju ännu bättre, det blir tråkigt om man måste styra jättemycket hela tiden, då blir det liksom inte det man vill. 30. Intervjuare: Nej.

31. David: Det här att de tar mer och mer ansvar själva, de vet vad de ska göra.

Vissa normer framträder i klassrummet: eleverna ska ta eget ansvar och samarbeta (32). Dessa förmågor, att samarbeta och ta eget ansvar, beskrivs samtidigt vara "svårt" för elevgrupperna. Lärarna menar att de vid behov hjälper eleverna i större utsträckning och att de bestämmer vilka elever som ska samarbeta med varandra. Lärarna gör därför ibland avkall på om eleverna gör "rätt" eller kommer fram till det "rätta" resultatet (33).

32. Pia: Jaa jo men det är ju så, nej men just det här men jag är klar nu. Jaa och vad kan du göra under tiden, kan du hjälpa till i den här gruppen? Det här att vara lite generös mot sina medmänniskor och lite så.

33. David: det inte blir rätt varje gång, det gör ingenting, utan det är vad som händer i gruppen som är viktigt, för det händer alltid något positivt.

Vidare betonas att undervisningen inte får vara tråkig om eleverna ska ta sig vidare i aktiviteten. Det praktiska arbetet med naturvetenskap och teknik kan i sig ge eleverna positiva upplevelser, men vid andra tillfällen förändras undervisningen så att den anknyter till verkligheten eller så att eleverna får använda flera sinnen, estetiska uttryckssätt, fantasi och kreativitet (34). Dessa arbetssätt beskrivs påverka elevernas engagemang och intresse. Engagerade elever ger också positiv feedback till lärarna.

34. Sam: Så de, det är väl det tycker jag, de här uppdragen i en NTA är ju gjorda så att man kan göra, genomföra dem och så, men man fär ju också lägga till ganska mycket tycker jag som lärare liksom för att öka kreativiteten, för det kan bli ganska låst om man bara kör det. Fast samtidigt så tycker de att det är roligt också att arbeta med händerna så, men de liksom, det är kul om man kan släppa lös lite mer $i$ kreativitet.

Även inom denna tradition betonas att elevernas förutsägelser inte behöver vara rätt. 


\section{Kommunikationsorienterade traditionen}

Inom den kommunikationsorienterade traditionen (5 lärare i 4 intervjuer) uttrycker lärarna att kommunikation, mellan lärare och elever, är viktigt för att eleverna ska ta sig vidare i aktiviteten. Den naturvetenskap och de nya begrepp vilka eleverna möter beskrivs vara "svåra" för eleverna, likaså beskrivs att uppdragens instruktioner är "svåra". För att hjälpa eleverna att ta sig vidare i aktiviteterna betonas klassrumsdiskussioner där elevernas arbete sammanfattas och återkopplas till tidigare lektioner (35-37) samt att de naturvetenskapliga begreppen kopplas till vardagsspråket (38). Lärarna beskriver också att elevernas erfarenhet eller vana av att arbeta undersökande har betydelse för hur arbetet fortskrider.

35. Emma: Så vi försöker, jag göra hela tiden att, ja vad man ska lära sig för någonting och ja vad vi tittar på idag och sedan försöker vi knyta ihop det på slutet också.

36. Intervjuare: $J a$.

37. Emma: Och sedan använda det till nästa gång också för det har jag ju märkt att om man inte gör det, är jätteintressant när man inte påpekar så där $i$ början och under tiden så kan man fråga eleverna sedan igen efteråt: Vad har vi gjort idag för någonting? Då vet de inte vad de gjort.

38. Kajsa: Men jag försöker ju använda de här vad ska man säga, korrekta då, vilket jag hoppas är korrekta naturvetenskapliga begreppen så mycket som möjligt, men att man inte bara svänger sig med dem om man ser att barnen inte förstår, utan att man hela tiden kopplar dem till, till vardagsspråket.

Lärarna säger inte att de undviker det eleverna upplever är tråkigt, men de uttrycker att elevernas upplevelser och engagemang för naturvetenskap och teknik har betydelse (39-41).

39. Emma: Ja, nä men jag kan ta den här kemilådan (...) när eleverna får, får droppa, jag kommer inte ihåg vad de får droppa då liksom, men det börjar bubbla och händer någonting sådär. De tycker de alltså, deras miner och blickar då vad intresserade de blir och ja, det tycker jag, men att se sådana saker, hur de, det tycker jag är ganska häftigt.

40. Intervjuare: $J a$.

41. Emma: När de verkligen liksom, åh, ja men vänta nu vad hände här nu å vad spännande det blev (...)

Inom traditionen beskrivs undersökande arbetssätt på flera sätt. Eleverna arbetar lite mera fritt eller i form av mer öppna undersökningar, där metod och resultat inte är förutbestämda (42). Lärarna beskriver också att de med klassen diskuterar planering av undersökningar och hur planeringen påverkar resultatet (43-46). Lärarna talar samtidigt om att elevernas förutsägelser inte behöver vara rätt. Inom denna tradition gör alltså eleverna även undersökningar där det finns ett förutbestämt rätt svar. Det är dock viktigt att elevernas förutsägelser bygger på tidigare erfarenheter, oavsett om dessa är riktiga eller ej (47). Här uppmuntras principen att bygga förutsägelser på något. Därmed beskrivs inte förutsägelserna som en ren gissning.

42. Kajsa: uppdraget innebär att de ska bygga en ficklampa, den ska ha en snygg design, lysa bra och ha en fungerande strömbrytare. Det är väl de tre huvudbitarna, så får de två, tre lektioner att jobba med det och det är också en sådan där riktigt, ja som de tycker är riktigt kul uppdrag, ganska tydliga instruktioner men ändå ganska fritt

43. Intervjuare: Hur gör du då när liksom det blir olika resultat?

44. Emma: Alltså det är väl bara bra för så blir det ju sedan också.

45. Intervjuare: $\mathrm{Ja}$

46. Emma: (...) det är ganska bra att man diskuterar det också: Hur ska vi göra då för att det ska bli ja, ett juste, vad ska vi göra? Ja då kanske man kör flera gånger istället, och tar ett genom- 
snitt och så där så att, det tycker inte jag gör någonting.

47. Kajsa: Viktigt att uppmuntra alla förutsägelser som bygger på något, och tala om faktiskt är det så för forskare också att de har ju byggt förutsägelser på fel saker

\section{Sammanfattning}

Sammanfattningsvis kan vi se att de olika traditionerna betonar olika kvalitéer i undervisningen. Tabell 1 visar exempel på några kvalitéer som betonas i traditionerna. Dessa kvalitéer berör främst undervisningens form, men har även betydelse för vilket innehåll eleverna erbjuds.

De kognitiva kvalitéer som berör svåra moment $i$ undervisningen betonas olika inom traditionerna. Svåra moment kan inkluderas eller exkluderas från undervisningen. Inom den faktaorienterade och aktivitetsorienterade traditionen finns tendensen att svåra moment som berör skriv- och läsförmåga utesluts, medan moment av praktiskt arbete inkluderas. Den samarbetsorienterade traditionen inkluderar främst förmågor som berör elevernas samarbete. Den kommunikationsorienterade traditionen är den som tydligast diskuterar svårt utifrån ett ämnesinnehåll.

De selektiva traditionerna har också olika förhållningssätt till normativa kvalitéer, särskilt elevernas arbete som fritt eller styrt. Den samarbetsorienterade traditionen har betoning på elevernas arbete som fritt eller styrt. Att elevgruppen arbetar fritt innebär att eleverna samarbetar, tar eget ansvar för arbetet, genom att de läser och följer instruktionerna. Ett annat förhållningssätt till att eleverna arbetar fritt beskrivs av den kommunikationsorienterade traditionen, där frågorna eller problemen är ställda, men där eleverna deltar i planeringen av hur undersökningen ska genomföras.

En skillnad mellan de selektiva traditionerna är också förhållningssättet till om eleverna gör rätt. Den faktaorienterade traditionen är den tradition som framförallt betonar betydelsen av att eleverna behöver följa instruktionerna rätt. Den aktivitetsorienterade traditionen betonar motsatsen, att det inte har någon betydelse om eleverna gör rätt eller fel.

Tre av de fyra selektiva traditionerna beskriver också betydelsen av estetik, till exempel att eleverna tycker att det är roligt eller tråkigt, vilket i sin tur påverkar lärarnas val av vad de inkluderar eller exkluderar i undervisningen.

Det framträder även några kvalitéer som är gemensamma för alla fyra traditionerna, nämligen att NO-undervisningen till viss del är praktisk. Gemensamt är också betoningen på att elevernas förutsägelser eller gissningar făr vara fel.

\section{Diskussion}

Vi har i denna studie valt att studera vilka selektiva traditioner som framkommer när ett relativt nytt sätt, undersökande arbetssätt med NTA, integreras i tidigare traditioner av tillvägagångssätt att undervisa. Vi kan se att lärarna har en förväntan att deras val av vad som ska inkluderas eller exkluderas leder till bättre undervisning (jfr Cherryholms, 2007). Genom beskrivningen av de selektiva traditionerna möjliggörs en reflektion över konsekvenserna av skilda betoningar för undervisningens syfte.

Studien tar sin utgångspunkt i tretton intervjuer med tjugo lärare vilka arbetar i grundskolans tidigare år. I studien syns ingen tydlig skillnad mellan lärare med olika bakgrund. Inom varje tradition finns såväl lärare med som utan tidigare erfarenhet av att undervisa i NO. Likaså finns inom varje tradition både lärare mot årskurserna F-3 och mot 4-6, förutom den aktivitetsorienterade traditionen, där lärarna enbart arbetar mot F-3. Vårt material är dock litet, endast tjugo lärare och därför kanske inte helt tillförlitligt i det avseendet. Flera svenska studier visar också att lärare i de svenska skolorna inte har så djupa kunskaper i området (Gyllenpalm, Wickman \& Holmgren, 2010; Högström, Ottander \& Benckert, 2006). Det är därför möjligt att även de lärare som har naturvetenskaplig lärar- 
utbildning har grunda kunskaper om undersökande arbetssätt. Det har dock inte varit vår avsikt att klassificera olika lärares undervisning, utan snarare beskriva olika selektiva traditioner och de kvalitéer som betonas inom dessa. Eftersom undersökande arbetssätt är en väsentlig del av NTA, har vi särskilt fokuserat på vad kvalitéerna inom traditionerna betyder för det innehåll eleverna erbjuds genom ett undersökande arbetssätt.

Tidigare studier av lärares arbete med undersökande arbetssätt har också visat på en variation från färdiga instruktioner till mer öppna undersökningar samt hur lärare värderar arbetssättet för att det upplevs som roligt, fritt och pedagogiskt genom de praktiska momenten (Gyllenpalm, Wickman \& Holmgren, 2010). Högström, Ottander och Benckert (2006), vilka studerade lärares mål med laborativt arbete, visade att lärarna framhöll generella mål framförallt inom det kognitiva området, medan specifika laborationer var riktade mot att utveckla praktiska och manipulativa färdigheter och affektiva mål. Vi kan se likheter mellan ovanstående studier och de kvalitéer denna studie beskriver. När lärarna i denna studie berättar om specifika uppdrag inom NTA beskriver de främst kvalitéer vilka har betydelse för praktiska färdigheter som "svårt att följa instruktioner" och "förutsägelserna făr vara fel" men också kvalitéer som har betydelse för social kompetens "svårt att samarbeta" samt affektiva kvalitéer vad som är "roligt" eller "tråkigt". Även om arbetssättet är relativt nytt för många av lärarna i grundskolans tidigare årskurser, tycks lärarnas värderingar av undervisning med undersökande arbetssätt likna de som lärare för grundskolans senare årskursers har för laborativt arbete. Vi kan också i likhet med Emanuelsson (2001) se att lärarna främst fokuserar på elevernas färdigheter, till exempel samarbetsförmåga, följa instruktioner rätt och det praktiska arbetet, snarare än innehållsliga kunskaper.

Trots betoningen på färdigheter beskriver enbart den kommunikationsorienterade traditionen undervisningsformer där eleverna erbjuds att vara delaktiga i planering och diskussioner om resultat och felkällor. Att eleverna ska lära sig att arbeta undersökande och utveckla en förståelse om naturvetenskapliga undersökningar uttrycks därmed inte inom alla traditioner, trots att det är ett mål i gällande läroplan Lpo 94.

Undersökande arbete används inom traditionerna som en undervisningsmetod med vars hjälp eleverna ska lära sig naturvetenskapliga förklaringar. Elevernas ska följa instruktionerna för att komma fram till ett förutbestämt rätt resultat. Det naturvetenskapliga ämnesinnehållet framstår därmed som något fast och något som eleverna kan upptäcka om de följer instruktionerna rätt, vilket är problematiskt, eftersom många naturvetenskapliga förklaringar inte är så uppenbara att de går att förstå genom att enbart observera (Bergqvist \& Säljö, 1994: Wickman \& Östman, 2002). För att nå slutsatser om bakomliggande naturvetenskapliga förklaringar behöver eleverna hjälp av läraren.

Inom flera traditioner tilldelas elevernas förutsägelser eller gissningar ett eget värde och något positivt just för att dessa inte behöver vara rätt. Att eleverna har svårt att acceptera att deras förutsägelser får vara fel i förhållande till undersökningsresultatet beskrivs däremot som problematiskt. Denna problematik påminner starkt om den rädsla elever i grundskolans senare år har för att formulera hypoteser enligt Gyllenpalm, Wickman och Holmgren (2010). Ytterligare en motsättning finns då eleverna å ena sidan ska kunna använda tidigare erfarenheter för att göra förutsägelser och därmed räkna ut vilket resultat en viss undersökning kommer att få och å andra sidan acceptera att de inte klarar av det (47). Det finns här ett behov av att diskutera syftet med att eleverna gör förutsägelser. Ett syfte med att eleverna gör förutsägelser kan vara att eleverna utifrån dessa får möjlighet att aktivt planera och genomföra undersökningen.

Tre av fyra selektiva traditioner betonar att undersökande arbetssätt engagerar eleverna och väcker intresse för naturvetenskap. Elevernas intresse beskrivs som en förutsättning för lärande i naturvetenskap och påverkar på så sätt lärares val av innehåll och metoder. Denna kvalitet får därmed betydelse för vilket innehåll eleverna erbjuds och kan ha betydelse för elevers socialisation i natur- 
vetenskap (jfr Jakobson \& Wickman, 2008; Wickman, 2006). Samtidigt som vi ser att estetiska kvalitéer har betydelse för elevernas trivsel, är det problematiskt om undervisningen som i den aktivitetsorienterade traditionen enbart betonar det lustfyllda på bekostnad av att eleverna också erbjuds ett kognitivt innehåll. Förhållningssätt som tillåter att affektiva kvalitéer går före begreppsliga mål har ifrågasatts. Southerland och Gess-Newsome (1997) argumenterar för att en sådan undervisning innebär att bara vissa elever lär sig undervisningsinnehållet, medan andra elever tillåts att komma efter så länge de är engagerade i aktiviteten. Det är viktigt att lärarna får hjälp att förstå hur estetiska och kognitiva kvalitéer kan förenas (Jakobson \& Wickman, 2008).

En motsättning finns mellan att eleverna ska göra rätt och ta ansvar för arbetet och att de samtidigt ska arbeta fritt utan hjälp från läraren. Ett liknande förhållningssätt har beskrivits av Andrée (2007), där det i en klass var mer osjälvständigt att be läraren om hjälp än att skriva av en klasskompis eller boken. Detta gjorde det svårt för eleverna att formulera slutsatser under laborationerna. Det var uppenbart att läraren behövde stötta eleverna med vad som var relevant och inte relevant i sammanhanget.

Två traditioner betonar att det språkliga, både tal och skrift, var något svårt och tråkigt vilket får konsekvensen att det reduceras eller exkluderas från undervisningen. Detta är problematiskt eftersom det innebär att eleverna inte erbjuds möjligheter att ta del av det naturvetenskapliga språkbruket och därmed begränsas även elevernas möjligheter att socialiseras in i kulturen (Lemke, 1990; Liberg, af Geijerstam \& Folkeryd, 2011).

En bra kvalité var också elevernas möjlighet att använda flera sinnen, estetiska uttryckssätt, fantasi eller kreativitet. Intressant i sammanhanget är att lärarna beskriver fantasi och kreativitet i samband med praktiskt arbete. Ingen nämner fantasi och kreativitet i mer teoretiska sammanhang, att det har betydelse för att "göra" naturvetenskap, till exempel för att dra slutsatser. Lederman (1998) menar att elever behöver få tala om dessa förhållanden om elever ska få erfarenheter av naturvetenskaplig kunskap som beroende av mänsklig slutledningsförmåga, kreativitet och fantasi.

Denna studie visar på olika kvalitéer i klassrummet, vilka, enligt lärarna, har betydelse för om eleverna kan ta sig vidare i aktiviteten eller inte. De kvalitéer traditionerna i studien betonar bland annat "att följa instruktioner rätt", "samarbeta", ha roligt" och "klassrumskommunikation". Dessa kvalitéer kan ses som ramar för vad lärarna vanemässigt inkluderar eller exkluderar i undervisningen och de har således betydelse för vilket innehåll eleverna erbjuds. Det behövs en fortsatt diskussion om innehållet och hur undersökande arbete kan bedrivas för att passa de tidigare årskurserna i grundskolan.

\section{REFERENSER}

Almqvist, J., Kronlid, D., Quennerstedt, M., Öhman, J., Öhman, M. \& Östman, L. (2008). Pragmatiska studier av meningsskapande. Utbildning och Demokrati., 17, 11-24.

Andrée, M. (2007). Den levda läroplanen: en studie av naturorienterade undervisningsaspekter $i$ grundskolan. Stockholm: HLS Förlag.

Bergqvist, K. \& Säljö, R. (1994). Conceptually blindfolded in the optics laboratory. Dilemmas of inductive learning. European Journal of Psychology of Education, 9, 149-158.

Carlone, H. B., Haun-Frank, J. \& Webb, A. (2011). Assessing equity beyond knowledge- and skillsbased outcomes: a comparative ethnography of two fourth-grade reform-based science classrooms. Journal of Research in Science Teaching, 48, 459-485.

Cherryholms, C. H. (2007). Utifrån vilka berättelser ska jag undervisa? Ingår i Boman, Y., Ljunggren, C. och von Wright, M. (red.) Erfarenhet av pragmatism (s. 105-123). Lund: Studentlitteratur.

DeBoer, G. E. (1991). A history of ideas in science education: Implications for practice. New York: Teacher College Press. 
Dewey, J. (1922/2005). Människans natur och handlingsliv: Inledning till socialpsykologin. Göteborg: Daidalos.

Duschl, R. A. (2008). Science education in three-part harmony: Balancing conceptual, epistemic and social learning goals. Review of Research in Education, 32, 268-291.

Emanuelsson, J. (2001). En fråga om frågor: hur lärares frågor i klassrummet gör det möjligt att få reda på elevernas sätt att förstå det som undervisningen behandlar i matematik och naturvetenskap. Göteborg: Göteborgs universitet.

Englund, T. (1986). Curriculum as a political problem. Changing educational conceptions, with special reference to citizenship education. Lund: Studentlitteratur.

Fensham, P. J. (1988). Development and Dilemmas in Science Education. London: The Falmer Press.

Gyllenpalm, J., Wickman, P.-O. \& Holmgren, S.-O. (2010). Secondary science teachers' selective traditions and examples of inquiry-oriented approaches. Nordina, 6, 44-60.

Harlen, W. (1997). Primary teachers' understanding in science and its impact in the classroom. $R e-$ search in Science Education, 27, 323-337.

Högström, P., Ottander, C. \& Benckert, S. (2006). Lärares mål med laborativt arbete: Utveckla förståelse och intresse. Nordina, 5, 54-66.

Jakobson, B. (2008). Learning science through aesthetic experience in elementary school. Stockholm: US-AB.

Jakobson, B. \& Wickman, P.-O. (2008). The roles of aesthetic experience in elementary school science. Research in Science Education 38, 45-65.

Johansson, A.-M. \& Wickman, P.-O. (2012). Vad ska elever lära sig angående naturvetenskaplig verksamhet? En analys av svenska läroplaner för grundskolan under 50 år. NorDiNa, 8, 197-212.

Kvale, S. (1997). Den kvalitativa forskningsintervjun. Lund: Studentlitteratur.

Lederman, N. G. (1998). The state of science education: Subject matter without context. Electronic Journal of science education [On-Line], 3(2), http://wolfweb.unr.edu/homepage/jcannon/ejse/ lederman.html

Lederman, N. G. \& Lederman, J. S. (2011). The development of scientific literacy: A function of interaction and distinction among subject matter, nature of science, scientific inquiry, and knowledge about scientific inquiry. Ingår i Linder, C., Östman, L., Roberts, D. A., Wickman, P.-O., Erickson, G. \& MacKinnon, A. (red) Exploring the Landscape of Scientific Literacy (s. 127-144). New York: Routledge.

Lemke, J. L. (1990). Talking science: Language, learning and values. Norwood, N. J.: Ablex Publishing.

Liberg, C., af Geijerstam, Å. \& Folkeryd, J. W. (2011). Scientific literacy and students' movability in science texts. Ingår i C. Linder, L. Östman, D. A. Roberts, P.-O. Wickman, G. Erickson \& A. MacKinnon (red.), Exploring the Landscape of Scientific Literacy (s. 74-89). New York: Routledge.

Permer, K. \& Permer, L. G. (2002). Klassrummets moraliska ordning. Iscensättande av lärare och elever som subjekt för ansvarsdiskursen $i$ klassrummet. Forskarutbildningen i pedagogik, Lärarutbildningen, Malmö högskola: Reprocentralen.

Sandell, K., Öhman, J. \& Östman, L. (2005). Education for sustainable development: Nature, school and democracy. Lund: Studentlitteratur.

Skolverket (1994). Lpo 94. Läroplan för det obligatoriska skolväsendet, förskoleklass och fritidshemmet. Stockholm: Skolverket.

Skolverket (2000). Grundskolans kursplaner och betygskriterier. Stockholm: Skolverket.

Southerland, S. A. \& Gess-Newsome, J. (1999). Preservice teachers' views of inclusive science teaching as shaping by images of teaching, learning, and knowledge. Science Education, 83, 131-150.

Sund, P. \& Wickman, P.-O. (2008). Teachers' objects of responsibility: something to care about in education for sustainable development? Environmental Education Research, 14, 145-163.

Wickman, P.-O. (2006). Aesthetic experience in science education: learning and meaning-making as situated talk and action. Mahwah, N.J.: Lawrence Erlbaum 
Wickman, P.-O. \& Östman, L. (2002). Induction as an empirical problem: how students generalize during practical work. International Journal of Science Education 24, 465-486.

Williams, R. (1973). Base and superstructure in Marxist cultural theory. New Left Review 82, 3-16.

Öhman, J. (2004). Moral perspectives in selective traditions of environmental education. Ingår i Wickenberg, P. (red.), Learning to change our world? (s. 33-57) Lund: Studentlitteratur.

Östman, L. (1995). Socialisation och mening: No-utbildning som politiskt och miljömoraliskt problem. Uppsala Studies in Education, 61. Stockholm: Almqvist \& Wiksell. 